\title{
ATTRACTING MILLENNIAL CONSUMERS IN THE DIGITAL AGE
}

\author{
ERIKA GRODZKi, SteFAnIE Powers, ANDREW BURnstine
}

\begin{abstract}
This study focuses on the recent fall of many large scale department stores (Macy's, J. C. Penney Company, Sear's, Kmart) and other retail, pharmacy and grocery stores (Bebe, Whole Foods, CVS, Chico's, Limited, Radio Shack, Game Stop) across the United States. The researchers set out to discover why stores that have existed for years suddenly had to shut down physical locations. The researchers hypothesized that these retail outlets have failed to properly attract millennial consumers. Marketers are endlessly attempting to find solutions on how to best attract millennials in this digital age. What appears to be evident, though, is that the habits of this demographic prefer the ease provided by online shopping. Secondary sources were reviewed to determine exactly why the stores have fallen. The millennial culture was a key component of the study. The results suggest that the stores failed due to improper targeting and in-store attraction.
\end{abstract}

Key words: consumer, millennial consumer, digital age, consumer needs

\section{Introduction}

In 2017, there was a retail apocalypse. Retail stores that had existed for decades, suddenly closed down. Fung Global Retail Tech (n.d.) also known as Coresight Research reports that 1,470 Radio Shack stores shut down as well as 700 Payless ShoeSource stores, 400 rue 21 stores, 358 Sears and Kmart stores, and 190 GameStop stores. The Business Insider reports that thousands of stores will close this year, "The record-high rate of store closures that rocked the retail industry last year has continued into 2018, with more than 3,800 closures expected this year (Peterson, 2018, para. 1). Toys R Us is in the process of closing all of its stores across the U.S. and Walmart closed 63 Sam's Club stores already. Pharmacies are closing as well. Walgreens/Rite Aid will be closing 600 of their stores this year. 
The purpose of this article is to discover why various department stores, retail and grocery stores are closing and also to find out how retailers and marketers can better target millennials. The researchers utilize secondary research to investigate the problem. The researchers hypothesize that the downfall of retail shops may in part be due to a misunderstanding of millenials and their consumption habits. Since millennials grew up with technology, they have different expectations and desires. They are sophisticated consumers that know what they want, when they want it and how they want it. The researchers will end the article with tips on how retail stores can change to better appeal to the generation.

\section{Defining Millennials}

Similar to all generational cohorts in the United States, Millennials or Generation Y share comparable ethics, values, and traits. There are some inconsistencies in the exact year that generations end and begin, nonetheless consensus characterizes Millennials as those born between the years of 1980 to 2000, following Genera+ tion $\mathrm{X}$ and forgoing Generation $\mathrm{Z}$. This generation grew up amid the September 11 terrorist attacks, throughout the wars in Iraq and Afghanistan, and during the 2008 election, where the first black president was elected, and it was clear that the voice of the youth vote became part of the political conversation (Dimock, 2018). Due to these cultural shifts in society, this generation is the "most racially and ethnically diverse adult generation in the nation's history" (Dimock, 2018, para. 8).

In addition to their cultural progression, these digital natives are celebrated for their "new generational personality - done of optimism, structure, team orientation, and a confidence bordering on entitlement," (U.S. Chamber of Commerce Foundation, 2017, para. 19). Millennials have been eyewitnesses to advances in technology, and are recognized for their understanding of emerging media and communication. This generations "main sources for news are the television $(65 \%)$ and the Internet (59\%). Lagging behind are newspapers (24\%) and radio (18\%)" (para. 13). Research also indicates surges in the quantity of time utilizing technology. "Millennials are never far away from their next text, with $80 \%$ sleeping with their cell phone next to the bed" (para 14). Due to the consistency of always being "on," research has shown shifts, both positively and negatively, in the mindset of this generation.

\section{Millennials as Consumers}

It is important to understand millennials as consumers. According to the U.S. Census Bureau (n.d.) in 2017, Millennials made up about 22 percent of the U.S. population. They have different wants and needs than past generations. Accord- 
ing to Pew Research Center (2015), Millennials spend twice as much time as boomers on self-care (dieting, therapy, working out). They are also more likely to have a bachelor's degree, to live at home longer and to be more liberal.

Millennials grew up with various technological devices. Since the generation is high on the technology curve (Norum, 2003), technology greatly influences their day to day lives. They are sophisticated consumers (Jackson, Stoel and Brantley, 2011; Wohlburg and Pokrywczynski, 2001). They rely on social media but when shopping, they prefer to shop online according to research by BigCommerce (2017) available via Statista. They sometimes, however, prefer to buy certain products in physical stores. They want you to be available, sometimes online and sometimes in the store (RedPrairie, 2012). They do not like to be bombarded with advertisements. Retailers and marketers should be strategic. It is vital to recognize millennials' preferences and make meaningful suggestions. They also do not like companies that overstep boundaries of privacy. Status is also important to the generation, in fact, even more so than past generations (Eastman and Liu, 2012).

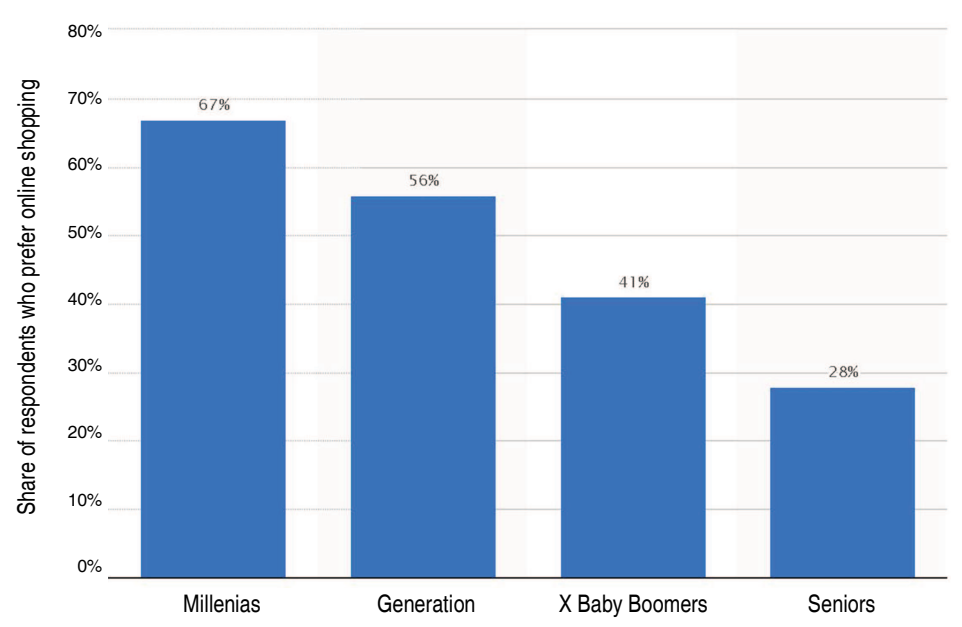

Figure 1. Online shopping in the United States as of 2017, by age group

\section{The Fall of Department Stores}

So many retail shops have closed in recent years. This includes department stores that have been around for ages as well as retail, pharmacy and grocery stores. One might wonder why this is happening. Richard Kestenbaum (2017) contributer for Forbes and co-founder and partner at Triangle Capital LLC writes, "So many stores are closing now for the same reason they've always closed - they don't meet 
consumers' needs" (para. 1). Kestenbaum explains that the original idea for retail was to develop a space for customers to choose from a wide array of products. Those products could be assembled and displayed in the store. It is now possible to find products online, therefore, the entire notion of bringing products to the consumer is no longer the same.

According to Kestenbaum, Millenials' desires are far different from those of baby boomers. Baby boomers wanted mass-produced products as well as global and generic products. They were also concerned with prestige. Millenials, claim prefer locally-sourced products that are ethnically made and environmentally friendly. They also prefer an artisanal, authentic and experiential environment. In an article titled Retail Realities, marketing research director Jeffrey Spivak (2018) explains how the suburb of Pittsburg outside of Oakland, California revitalized its downtown. The author states that the suburb tried to initially follow a traditional mindset by trying to replace department stores that closed down. That strategy failed. The idea now is to not rely on retail and to open up the downtown area with different types of businesses such as fitness facilities and office spaces. This is happening across the U.S., "[t]he goods-based consumer retail industry is undergoing a seismic shift and transformation" (p. 16).

While brick and mortar department store sales have fallen, Amazon's virtual marketplace has surged. Millenials make more and more of their purchases online. According to an article published in USA Today (Blumenthal, 2016) millennials play a significant role in the decline of large department stores. Amazon's sales have continually increased reports Lauren Thomas (2018) retail reporter for CNBC, "Amazon was responsible for about 44 percent of all U.S. e-commerce sales last year, or about 4 percent of the country's total retail sales figure, according to data from One Click Retail” (para. 1). Data from a research study by eMarketer (n.d.) available via Statista shows that Amazon marketplace sales have drastically increased since 2016 and are expected to reach almost 230 billion dollars in 2019.

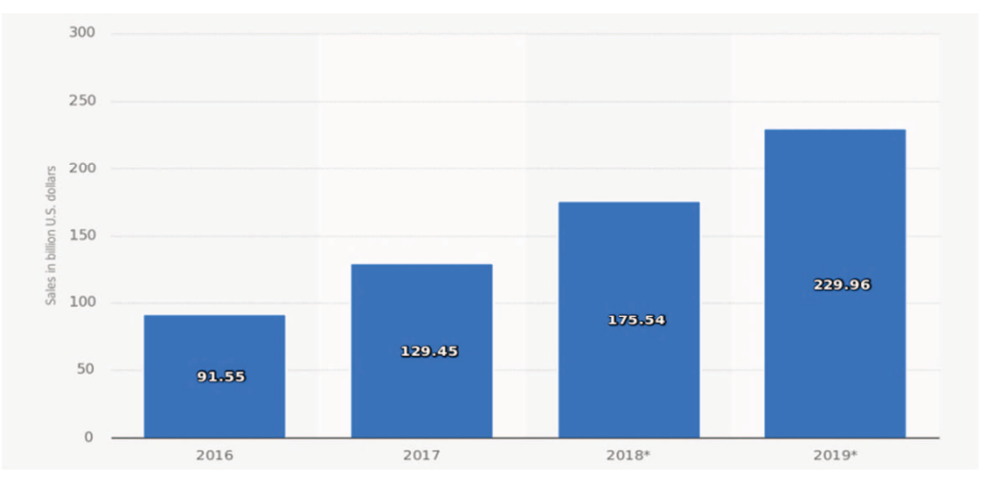

Figure 2. Amazon marketplace sales in the United States from 2016 to 2019 (in billion U.S dollars) 


\section{Revitalizing Retail for Millennials}

In order to appeal to millenials retailers must realized that customer service is important. Millennials like sales representatives to be friendly but not pushy. Millennials will buy some products online yet prefer to buy some products onground and they do expect a seamless transition between the two. The retail space should be clean, bright and well-organized. They should be able to quickly find their favorite brands. Price and sales matter to millennials. According to a PWC study (2016), 59 percent of millennials responded that they shopped at their favorite retailer because they were 'price conscious' consumers. It is also important for millennials that retailers and marketers are ethical in their management. Millennials are concerned with both advertising strategies and privacy concerns. Finally, natural, environmental-friendly and local and artisan products are preferred (Kestenbaum, 2017).

\section{Conclusion}

The researchers set out to examine secondary research to discover why various department stores, retail and grocery stores are closing. The findings suggest that stores are closing because they do not meet consumer needs. Technology has forced retail to change. Products are now available online and consumer are savvy. Retailers must change to better appeal to Millennials by offering products that appeal to them. Spivak (2018: 20-21) claims that brick-and-mortar shops will still be around in the future, "[i]t still accounts for some 90 percent of total retail sales". Retailers must adapt to Millenials and create spaces, experiences and products that are appealing.

** The authors would like to thank Daniel Chavez for his assistance in the research process.

\section{References}

Eastman, J.K., Iyer, R. and S.P. Thomas. 2013. "The impact of status consumption on shopping styles: an exploratory look at the millennial generation”. Marketing Management Journal 23(1). 57-73.

Eastman, J. K. and J. Liu. 2012. "The impact of generational cohort on status consumption: an exploratory look at generational cohort and demographics on status consumption". Journal of Consumer Marketing 29(2). 93-102.

Jackson, V., Stoel, L. and A. Brantley. 2011. "Mall attributes and shopping value: differences by gender and generational cohort". Journal of Retailing and Consumer Services 18(1). 1-9.

Norum, P.S. 2003. "Examination of generational differences in household apparel expenditures". Family and Consumer Sciences Research Journal 32(1). 52-75.

Spivak, J. 2018. "Retail realities". Planning 84(7). 14-21. 


\section{Internet Sources}

BigCommerce. (n.d.). Online shopping preference in the United States as of 2017, by age group. In Statista - The Statistics Portal. Retrieved from https:/lynn-lang.student.lynn.edu:2093/statistics/ 242512/online-retail-visitors-in-the-us-by-age-group/.

Dimock, M. (2018, March 01). Defining generations: Where Millennials end and post-Millennials begin. Retrieved August 31, 2018, from http://www.pewresearch.org/fact-tank/2018/03/01/defining-gene rations-where-millennials-end-and-post-millennials-begin/

eMarketer. (n.d.). Amazon marketplace sales in the United States from 2016 to 2019 (in billion U.S. dollars). In Statista - The Statistics Portal. Retrieved from https://lynn-lang.student.lynn.edu:2093/ statistics/882919/amazon-marketplace-sales-usa/.

Kestenbaum, R. (2017, April 17). Why so many stores are closing now. Forbes. Retrieved from https://www. forbes.com/sites/richardkestenbaum/2017/04/07/why-so-many-stores-are-closing-now/\#9a97b3d41593

Peterson, H. (2018, April 7). More than 3,800 stores will close in 2018 - here's the full list. Business Insider Retrieved from https://www.businessinsider.com/stores-closing-in-2018-2017-12.

PLMA. (n.d.). What matters most to Millennials when choosing where to shop?. In Statista - The Statistics Portal. Retrieved from https://ynn-lang.student.lynn.edu:2093/statistics/317798/us-millennials-most-important-aspects-when-choosing-where-to-shop/.

PWC. (February 2016). Millennials: Thinking of your favorite retailer, why do you shop here?. In Statista - The Statistics Portal. Retrieved from https://lynn-lang.student.lynn.edu:2093/statistics/631097/ reasons-why-us-millennials-shop-at-their-favorite-retailers

RedPrairie. (2012). The Millennial Report. Retrieved from https://risnews.com/secure-file/13463.

Thomas, L. (2018, Jan. 3). Amazon grabbed 4 percent of all US retail sales in 2017, new study says. CNBC. Retrieved from https://www.cnbc.com/2018/01/03/amazon-grabbed-4-percent-of-all-us-retailsales-in-2017-new-study.html.

U.S. Census Bureau. (May 16, 2017). Quarterly retail e-commerce sales 1st quarter 2017. Retrieved from https://www.census.gov/retail/mrts/www/data/pdf/ec_current.pdf

US Census Bureau. (n.d.). Population distribution in the United States in 2017, by generation . In Statista - The Statistics Portal. Retrieved from https://lynn-lang.student.lynn.edu:2093/statistics/296974 /us-population-share-by-generation/.

U.S. Chamber of Commerce Foundation (2017, March 15). The Millennial Generation Research Review. Retrieved from https://www.uschamberfoundation.org/reports/millennial-generation-researchreview. 